\title{
O PAPEL POLÍTICO DO PODER JUDICIÁRIO NA EFETIVAÇÃO DO DIREITO À SAÚDE DO TRABALHADOR: ENFOQUE NAS DEMANDAS ACIDENTÁRIAS
}

\author{
THE POLITICAL ROLE OF THE JUDICIAL POWER IN \\ EFFECTING THE WORKER RIGHT TO HEALTH: FOCUS ON \\ ACCIDENT DEMANDS
}

\author{
Catarine Helena Limeira Pimentel ${ }^{1}$ \\ Maria Áurea Baroni Cecato ${ }^{1}$
}

Recebido em: 21/08/2016 Aceito em: 22/09/2016

catarineh@yahoo.com.br mariaaurea.cecato@gmail.com
Resumo: O direito à saúde tem recebido novas perspectivas no Poder Judiciário, que vem substituindo o positivismo por modernas teorias de interpretação do direito, como no realismo jurídico norte americano. Objetivando efetivar direitos fundamentais, a proatividade judicial pode proporcionar transformações jurisdicionais e práticas, buscando promover um meio ambiente do trabalho saudável. Com abordagem doutrinária e jurisprudencial, objetiva-se demonstrar que a atuação do Judiciário pode afluir para promoção da saúde do trabalhador, alcançando soluções criativas que confiram máxima efetividade à Constituição Federal. Aplica-se o método dedutivo em abordagem conceitual e teórico-normativa.

Palavras-chave: Decisão Judicial. Direito à Saúde. Meio Ambiente do Trabalho. Poder Judiciário. Proatividade Judicial.

Abstract: The right to health has received new prospects in the Judicial Power, substituting the positivism by modern theories of interpretation of law, as in the North American juridical realism. Aiming at effecting fundamental rights, the judicial proactivity can provide jurisdictional transformations and practices, seeking to promote an environment of healthy work. Following a doctrinaire and jurisprudential approach, this paper tries to demonstrate that the action of the Judicial Power can result into promotion of the worker health, leading to creative solutions which concede maximum effectiveness to the Federal Constitution. One applies the deductive method to conceptual and theoretical-normative approaches.

Keywords: Judicial Decision. Right to Health. Work Environment. Judicial Power. Judicial Proactivity.

\section{INTRODUÇÃO}

Diante das estatísticas alarmantes de acidentes trabalho, em um mundo em que o labor se faz prioritariamente de forma intensa e precária, vem se consolidando uma cultura de prevenção a fim de promover efetivamente a saúde no trabalho. Nesse quadro, torna-se dificilmente justificável a indiferença por parte do Estado, especialmente do Poder Judiciário, guardião do ordenamento jurídico pátrio e ao qual recorrem as vítimas acidentárias. É, igualmente, nesse quadro, que se discute a assunção, pela Justiça do Trabalho, de postura ativa em prol da sociedade, envidando esforços no sentido da redução dos riscos causados aos trabalhadores pelos mencionados acidentes.

A dificuldade parece se colocar na compreensão de como o Poder Judiciário poderia operar ativamente em prol da comunidade de trabalhadores e prevenir os riscos, se nas ações judiciais o

\footnotetext{
${ }^{1}$ Universidade Federal da Paraíba - UFPB - João Pessoa - Paraíba - Brasil.
} 
bem jurídico (saúde ou vida) normalmente já sofreu lesão. Dessa forma, definiu-se que o problema central da presente pesquisa deve se traduzir na seguinte questão: Que possibilidades tem o Poder Judiciário, à luz da Constituição Federal, de concorrer para a promoção da sadia qualidade de vida do trabalhador no meio ambiente laboral, considerando-se a limitação da atuação do aludido poder na conformação clássica da divisão dos poderes.

Considerando a impotência das decisões judiciais diante da comum impossibilidade de restituição do bem jurídico lesado, apresenta-se, como hipótese, que a atuação do Poder Judiciário pode ser proativa, adotando teorias realistas para interpretação das normas e buscando soluções criativas no intuito de conferir máxima efetividade ao direito fundamental à saúde, atribuindo qualidade e eficiência à prestação jurisdicional.

Nesse cenário encontra-se igualmente o objetivo principal deste texto, o qual se volta para a busca da demonstração de que a atuação do Poder Judiciário pode afluir para a promoção da sadia qualidade de vida do trabalhador no meio ambiente laboral, malgrado as limitações que se estabelecem a essa mesma atuação pelos princípios e normas concernentes à divisão dos poderes.

Neste texto aplica-se o método dedutivo em uma abordagem conceitual e teórico normativa, utilizando-se decisões judiciais do TRT da 13르 Região, com o fito de reforçar os argumentos.

Tratar-se-á, inicialmente, da evolução de teorias de interpretação das normas a partir do positivismo, seguindo para a aplicação de normas processuais e constitucionais diante da realidade das demandas trabalhistas. Aborda-se, finalmente, a decisão judicial como ferramenta assecuratória da saúde dos trabalhadores, onde se pretende demonstrar como a proatividade judicial pode privilegiar os fins sociais da decisão, contribuindo para a efetivação do direito constitucional à saúde, sem ferir o princípio da separação dos poderes.

\section{EVOLUÇÃO DAS TEORIAS DE INTERPRETAÇÃO DE NORMAS PARA EFETIVAÇÃO DO DIREITO À SAÚDE EM DECISÕES JUDICIAIS}

O positivismo do final do século XVIII defende a responsabilidade do Parlamento pela elaboração e generalidade das normas, cabendo às Cortes Judiciais tão somente o reconhecimento do direito aplicável ao caso concreto, jamais sua criação. Ao julgador caberia apenas o papel de voz da lei, da qual, se bem aplicada, emana uma única decisão acertada. Nesta fase exegética do positivismo, a ciência do Direito é retratada pela aplicação mecânica e literal da lei, sem possibilidade de inovações, sendo a norma o próprio Código.

Uma nova perspectiva positivista surgiu com a Teoria Pura do Direito de Hans Kelsen que reconhece a existência de várias camadas de normas "supra-infra-ordenadas umas às outras" (KELSEN, 1998, p. 141), validadas pela norma fundamental pressuposta (1998, p. 139), de forma que a interpretação autêntica cria direitos podendo seu resultado assumir forma de lei ou sentença, a depender do órgão aplicador do Direito. Portanto, a decisão judicial seria uma norma individual inferior, cuja produção respeita os critérios da norma superior que the determina, cabendo-lhe analisar qual o significado da lei adequado ao caso para criar o direito que regerá os litigantes. Verificando que a indeterminabilidade da norma e o caráter plúrimo dos seus significados conferem 
várias possibilidades de aplicação jurídica, ao magistrado é dada a discricionariedade necessária para escolha do sentido da norma aplicável, compondo o que Kelsen chama de moldura jurídica, na qual se inserem todas as normas individuais possíveis (KELSEN, 1998, p. 247), significando em ato de escolha das opções antevistas pela Ciência e não de interpretação da norma (GOMES, 2009, p. 45). Isto porque o Direito positivo seria uma realidade jurídica isenta de ideologias, sem influência de "juízos de valor subjetivos, que encobre, obscurece ou desfoca o objeto do conhecimento" (KELSEN, 1998, p. 74-75), decorrendo a pureza do alicerce exclusivamente normativo, expurgando conceitos como moral e justiça, que podem ser contrariados pela ordem jurídica válida (KELSEN, 1998, p. 47). Para o Direito, não importaria nada além do valor jurídico, afastando os subsídios metajurídicos e sobrelevando o ser em contrapartida do dever-ser.

Divergindo do positivismo kelseniano, teorias pós-positivistas defendem a interpretação como elemento necessário à própria criação, sendo a norma o resultado da combinação entre o texto normativo e o caso concreto. Neste sentido, Müller (2005, p. 38/39), apresentando sua Metódica do Direito Constitucional, defende que a normatividade manifestada nas decisões não está orientada apenas pelo texto da norma jurídica concretizanda, mas transcende sua literalidade, inclusive com normas de moral e justiça. Objetivando concretizar a Constituição, trata de hermenêutica constitucional pelo método materialista concretista, reputando injustificável a ausência de materialização das normas constitucionais em um Estado Constitucional de Direito, que tem a Constituição, com conteúdo eminentemente valorativo, como alicerce de todo ordenamento normativo.

Diante da crise do positivismo e das novas correntes hermenêuticas, observa-se o surgimento de correntes cada vez mais materializadoras, a exemplo dos fenômenos do ativismo judicial e da judicialização da política ou politização do Judiciário, para onde se transferem discussões políticas, originariamente de outros Poderes, notadamente do Parlamento, como resultado de um novo padrão de interpretação e aplicação do direito através da primazia dos direitos fundamentais e concretização de direitos, aumentando a responsabilidade do Poder Judiciário e redefinindo os contornos de suas funções (BARBOZA; KOZICKI, 2012, p. 1-2). Dá-se continuidade ao "boom da litigação" (VIANNA; BURGOS; SALLES, 2007, p. 2), nascido desde o fim da repressão ditatorial em razão do desejo de justiça e efetivação dos direitos no emergente Estado Democrático.

A ampliação da norma permite o magistrado concretizar os direitos humanos considerando as especificidades do caso concreto e criando o direito de forma semelhante ao common law, razão porque as teorias realistas norte-americanas têm sido aplicadas. Os opositores do judicial review defendem a ilegitimidade do Judiciário e o acusam de usurpação de poderes, sob argumento de não serem, os juízes, eleitos democraticamente pelo povo. Ocorre que a aplicação da Constituição é atividade judicial típica, não convindo a ilegitimidade apontada se o objetivo primordial do magistrado é legitimá-la. Além disso, é o próprio povo e suas representações políticas que provocam o Poder Judiciário e legitimam sua atuação, cuja prestação jurisdicional é inafastável (art. 5ํㅡ, XXXV, CF). Na prática, os resistentes apontam barreiras formais no processo (MELLO, 2004, p. 218-220), entre as quais podemos citar a inércia da jurisdição e a adstrição ao pedido, que vedam os julgamentos extra e ultra petita. De fato, não se pode negar os métodos restritivos, pois os limites são imprescindíveis 
ao bom funcionamento do Estado Democrático de Direito, o qual não prescinde do sistema de freios e contrapesos, além de se adequar ao devido processo legal.

Assim, não se defende a ideia de conferir ao Judiciário poderes irrestritos, nem para elaborar leis ou contrariá-las, mas a observância dos valores substancialmente fundamentais através de soluções criativas permitidas pelo ordenamento jurídico, respaldadas por interpretações que confiram máxima efetividade às normas constitucionais. Assim, a tendência ampliativa funcional do Judiciário torna-se inevitável para concretizar direitos constitucionais fundamentais como a vida e a saúde, devendo os julgadores proporcionar o efetivo gozo dos direitos negados ou violados, desempenhando o constitucionalismo transformador, cuja essência é cumprir a Constituição.

Dessa forma, a defesa do direito à saúde é tarefa que exige o papel ativo do Poder Judiciário, notadamente em prol dos cidadãos economicamente desprovidos como os trabalhadores subordinados, sem poder de negociação devido à necessidade de sobrevivência e dependência ao capital, que os tornam submissos a precárias situações no ambiente do trabalho, como jornadas extenuantes e exposição a riscos de morte. Diante disso, a neutralidade que sempre caracterizou o Judiciário vem tomar nova feição. Embora deva o juiz permanecer neutro em relação às partes que litigam, deverá tomar partido da sociedade para the garantir direitos que transcendem o indivíduo. Assim, proporcionar a proteção de bens jurídicos transindividuais, coletivos ou difusos deve ser uma preocupação judicial mesmo fora das demandas coletivas.

Por conseguinte, o direito à saúde pode ser protegido pelo Poder Judiciário do Trabalho de forma macrossocial através do julgamento que amplia a segurança nos ambientes de trabalho. CabeIhe garantir o gozo de direitos ignorados pelos empregadores e pelo Estado, por ineficiência ou mau uso de verbas, e apesar de não ser o Judiciário responsável primário por implementar políticas públicas de proteção à saúde, não deve se limitar à reprodução das normas elaboradas pelos demais Poderes, mas, ativamente, fomentar o respeito às normas.

Neste sentido, é possível adotar fundamentos das teorias realistas na produção das normas individuais, céticas quanto ao conhecimento preciso, através das quais podem os juízes se valer de normas não positivadas, pois a efetividade da decisão é o que realmente importa. Assim, no intuito de tornar o processo mais efetivo, é comum no dia a dia dos tribunais encontrar decisões aparentemente contrárias à norma. A título de exemplo, em execução processual trabalhista, pode ocorrer o direcionamento precoce dos atos de constrição à empresa condenada subsidiariamente, mesmo sem esgotamento dos atos executórios contra a executada principal, tomando emprestado elementos alheios ao processo, seja uma insolvência pública e notória, sejam diligências infrutíferas operadas em outras execuções. Nestes casos, o cumprimento rigoroso da lei provocaria atos inúteis e custos desnecessários, cabendo ao juiz prezar por efetividade, economia e celeridade. Para o realismo jurídico, a adoção de uma abordagem metodológica pragmática poderá conferir maior eficiência à atividade judicante, afastando da interpretação jurídica excessos de formalismos e abstrações com discussões metafísicas infindáveis, dando lugar à preocupação com a clareza e consequências práticas da decisão para conferir soluções úteis. (houve supressões neste parágrafo)

É fato que, por mais objetividade que se espere, o julgador não está imune aos seus instintos, crenças, convicções adquiridas e concepção das necessidades sociais (CARDOZO, 2004, p. 3). 
Portanto, defendendo o magistrado como agente ativamente envolvido com a sociedade, a teoria realista não nega inevitáveis influências moralizantes e vulnerabilidade à própria filosofia de vida do julgador, motivo pelo qual considera o processo de decisão ideológico.

Com base na teoria de Cardozo (2004), se o Juiz é criador de direitos, deverá ele dar maior utilidade social às suas decisões, pois apesar da subordinação da decisão judicial à lei e aos precedentes jurisprudenciais, não existe nada imutável, sejam precedentes, leis ou até princípios, pois não existem verdades absolutas. Considerando o método experimental do Direito, as soluções são submetidas a testes nos laboratórios do Direito, os tribunais, e caso os resultados não eliminem as controvérsias, serão gradualmente reavaliados.

Assim, fundado na filosofia pragmática, o realismo jurídico norte americano se caracteriza pelo ceticismo quanto às normas e conceitos jurídicos, rechaçando o legalismo e defendendo o direito como aquilo que o juiz diz que é direito, sendo a norma jurídica utilizada na decisão apenas como justificação a posteriori (FREITAS, 2009, p. 143). Para fundamentar as decisões judiciais, portanto, o caráter retórico-principiológico do direito contemporâneo contribui para essa nova e essencial postura do Judiciário.

Todavia, o direito dos juízes é subordinado ao ordenamento jurídico, sendo óbvia a adequação da lei ao caso, esta deve ser aplicada, do contrário, cabe ao julgador suprir lacunas, ambiguidades, desarmonias e injustiças, aplicando analogia, costumes e princípios gerais do direito, tornando a atividade judicante dinâmica, indispensável e eficaz aos reclamos sociais. Ora, se do direito de ação resulta o direito à prestação jurisdicional, o princípio da inafastabilidade fará o juiz empregar sagacidade intelectual e criativa na elaboração do direito aplicável à situação para a qual não há clara solução normativa, sem que a discricionariedade para interpretar e aplicar as leis implique ruir no arbitrário. Assim, havendo mais de uma norma aplicável, deve o magistrado interpretar o ordenamento jurídico aplicável de forma a conferir máxima efetividade às normas constitucionais, cabendo-Ihe ser proativo na busca de solução eficaz aos problemas sociais, de forma mais ampla possível.

Consciente o magistrado de que o legislador jamais conseguirá prever todas as situações que surgirão em uma sociedade acentuadamente abstrusa, torna-se claro que o pragmatismo e o realismo jurídico possibilitam uma atuação proativa e eficiente do Poder Judiciário que, avaliando a sociedade com sensatez, sem superestimar ideais dificilmente concretizáveis, atuará em benefício da efetivação dos direitos humanos, conferindo às decisões judiciais maior utilidade social.

\section{APLICAÇÃO DE NORMAS PROCESSUAIS E CONSTITUCIONAIS DIANTE DA REALIDADE DAS DEMANDAS TRABALHISTAS}

No ordenamento brasileiro, o Poder Judiciário representa o Estado interventor nos conflitos sociais não consensualmente solucionados e, através da figura do juiz, identifica a lei aplicável e Ihe confere o significado que reputa mais justo e eficiente ao deslinde do caso, não the cabendo, em regra, criar normas abstratas. Contudo, o processo do trabalho apresenta particularidades que fogem à regra, como as sentenças normativas emanadas dos TRTs ou TST, cujas decisões são proferidas 
nos dissídios coletivos e criam normas de caráter geral e abstrato, estabelecendo condições de trabalho para determinada categoria econômica e profissional, dotando o órgão julgador de poderes normativos semelhantes aos dos órgãos legislativos. Na oportunidade, é possível estabelecer obrigações ao empregador no intuito de proteger a saúde e o bem-estar dos trabalhadores.

A sentença normativa nasceu no Brasil em meio a divergências. De origem italiana, surgiu na fase administrativa da Justiça do Trabalho, antes de sua incorporação ao Poder Judiciário, em 1946. Nascimento (1980, p. 71) analisou o debate - aliás, polêmico - havido, na ocasião, e que culminou com a adoção da teoria inspirada no realismo jurídico norte americano e consequente poder normativo da Justiça do Trabalho. É esse mesmo autor (1980, p. 72) que justifica a aludida adoção do modelo italiano, considerando que o Direito "[...] é um instrumento de que devemos nos utilizar para o progresso e a ordem", não havendo razão para separação de poderes, senão para beneficiar a sociedade.

A prevalência da tese pragmática culminou na criação das sentenças normativas, cuja elaboração retrata o poder tipicamente legislativo atribuído ao Judiciário, percebendo-se, há décadas, que o legítimo valor da tutela jurisdicional é concretizar o Direito amplamente e não apenas solucionar um litígio. Entretanto, não se nega a necessidade de limites que apartem arbitrariedades, pois as normas processuais e procedimentais são de fundamental importância para segurança jurídica e padronização das rotinas.

Uma das regras limitadoras mais básicas do direito processual é prevista pelo art. 141 do NCPC, ao disciplinar que "O juiz decidirá o mérito nos limites propostos pelas partes, sendo-lhe vedado conhecer de questões não suscitadas a cujo respeito a lei exige iniciativa da parte". A tese é ratificada pelo art. 492 ao tratar a lei processual dos requisitos da sentença, afirmando ser "É "[...] vedado ao juiz proferir decisão de natureza diversa da pedida, bem como condenar a parte em quantidade superior ou em objeto diverso do que the foi demandado". Conforme tais preceitos, a decisão deve deliberar exatamente as questões apresentadas, refutando-se o pronunciamento além dos pedidos (ultra petita), fora dos pedidos (extra petita) ou aquém dos pedidos (citra petita). Frente a isso, novamente o processo do trabalho demonstra seu viés pragmatista ao possibilitar o tribunal competente julgar o dissídio coletivo estendendo as condições de trabalho estabelecidas em sentença normativa aos demais empregados da empresa cuja profissão seja idêntica à dos dissidentes (Art. 868, CLT). Assim, julgando justo e conveniente, poderá ampliar os efeitos da decisão além dos limites processualmente estabelecidos, estendendo a todos os empregados da mesma categoria profissional dentro da sua jurisdição, a pedido ou de ofício, desde que preenchidos os demais requisitos legais (Art. 868 a 871, CLT).

Observa-se que a relativização de princípios como a separação de poderes e proibição de julgamento extra ou ultra petita é prevista no próprio ordenamento jurídico e justificada pelo fidedigno propósito de cumprir princípios fundamentais da República como o valor social do trabalho. Portanto, garantindo os direitos fundamentais do trabalhador, o Judiciário cumprirá os objetivos de construir uma sociedade justa, reduzir as desigualdades e promover o bem de todos. Tais alicerces constitucionais devem motivar a atuação dos julgadores em reprimenda a graves violações, ou riscos de violações, aos direitos humanos, e respaldar as interpretações normativas.

Revista do Direito [ISSN 1982-9957]. Santa Cruz do Sul, v. 2, n. 49, p. 154-170, maio/ago. 2016. https://online.unisc.br/seer/index.php/direito/index 
A interpretação e o emprego das normas devem objetivar o bem comum e não apenas interesses individuais, sob pena da subutilização causar injustiça social. Ressalta-se, porém, que a interpretação contra legem não é permitida, exceto para prevalência das normas constitucionais, seguindo os parâmetros da hermenêutica jurídica. Neste sentido, Streck (2010, p. 171-172) menciona exceções entre as quais, juntamente com a inconstitucionalidade das leis, está a interpretação da lei conforme à Constituição e a aplicação principiológica em detrimento da aplicação literal da lei. $\mathrm{O}$ autor ressalta, porém, a necessidade de cuidados no afastamento da literalidade da lei, sendo "[...] necessário compreender os limites e os compromissos hermenêuticos que exsurgem do paradigma do Estado Democrático de Direito".

Não há dúvidas de que o magistrado deve cumprir as disposições legais, sempre buscando a mens legis, sem ignorar a distância triangularmente equitativa estabelecida com as partes e afastar qualquer sentimentalismo que macule sua decisão, muito embora ser quase impossível atingir uma neutralidade ideológica. Entretanto, em caso de impossibilidade, seja por omissão, contradição ou qualquer discrepância entre os fatos e as normas, devem os juízes observar os princípios constitucionais e métodos hermenêuticos para elaboração da decisão.

O método de interpretação conforme à constituição existe para ratificar a prioridade de aplicação das normas constitucionais, impondo ao magistrado cumpri-las rigorosamente em detrimento de leis que, embora constitucionais, tornam-se inaplicáveis ao caso concreto sob pena de contrariar princípios fundamentais. Ora, dar máxima efetividade às normas constitucionais é o objetivo hermenêutico imperativo em um Estado Democrático de Direito. Sendo assim, o direito à vida e à saúde, bens jurídicos protegidos por toda extensão da Constituição Brasileira, jamais poderão ficar à míngua do trabalhador.

$\mathrm{Na}$ prática, é preciso enxergar além das reclamações trabalhistas que objetivam, em sua maioria, apenas ressarcimento moral e material pelos prejuízos à saúde psíquica ou física do trabalhador. A iniciativa de demandar somente após a rescisão contratual e o acidente se justifica pelo temor ao desemprego, pois dificilmente os empregados acionarão seus empregadores no intuito de pleitear melhores condições de trabalho, ou rescisão indireta por descumprimento das obrigações contratuais, se sua sobrevivência estiver em risco.

Paralelamente a isso, a vítima de acidente no trabalho que aciona judicialmente o empregador, ainda que tenha êxito na demanda, nada contribuirá para melhoria do ambiente onde se acidentou, exceto se o próprio empregador for suficientemente diligente para investir em progressos e evitar novos infortúnios. Tal comportamento, entretanto, não é o mais provável, nomeadamente no contexto atual em que as empresas primam por conter despesas. Mas, se diante do magistrado há ameaça de lesão a trabalhadores alheios àquela relação processual, seria seu único papel oficiar ao Ministério Público do Trabalho para intervir e possivelmente ingressar nova ação judicial, retornando o caso à apreciação do Poder Judiciário? Não poderia o juiz atuar de ofício na busca de resguardar a segurança dos demais trabalhadores que vivem boa parte do dia em ambiente comprovadamente arriscado?

Observa-se a conjuntura desfavorável a que o trabalhador se submete, razão porque é alarmante o número de acidentes. O mais recente Anuário Estatístico de Acidentes do Trabalho 
(AEAT) elaborado pela Previdência Social, referente ao período de 2012 a 2014 e divulgado em março de 2016, aponta 722.474 acidentes liquidados em 2014, dos quais 2.783 resultaram em óbito. Realizando simples cálculos aritméticos é possível concluir que houve diariamente, em média, quase dois mil acidentes, dentre os quais quase oito óbitos, ou seja, 1 morte a cada 3 horas decorrente de acidentes de trabalho. Sendo assim, quando a ação ministerial for ajuizada milhares de trabalhadores já terão morrido, sido mutilados ou contraído doenças que poderão limitar suas capacidades por toda a vida.

Tal realidade se repete anualmente, sendo o agravamento das estatísticas contínuo, além de consequência natural do avanço tecnológico e da produção em massa provocada pela sociedade dos descartáveis (ANTUNES, 2005, p. 15). Portanto, é imprescindível intensificar as políticas públicas de segurança no trabalho, além de flexibilizar a atividade jurisdicional que não deve se limitar à elaboração de decisões com teores contornados por partes repletas de interesses egoísticos. Nesse cenário, dever-se-ia dizer que o Estado, enquanto executor de atividades jurisdicionais, restringindose ao conflito entre duas partes e à simples comunicação da ilicitude empregadora aos órgãos fiscais, quando é o responsável pelo bem-estar de todos, perde excelentes oportunidades de se aproximar do alcance do mencionado bem-estar, contendo ou reduzindo graves violações do direito à vida.

Ora, em que pese a relevante atuação de instituições como Ministério Público do Trabalho, Ministério do Trabalho e Emprego e sindicatos profissionais, que agem conjunta e individualmente para proteção do trabalhador, os complexos problemas sociais e a necessidade de medidas urgentes exigem novas posturas do Poder Público. À inefetividade de normas, ações fiscalizatórias, programas governamentais e ações judiciais, devem ser somados tantos meios quantos sejam possíveis para garantir a segurança dos trabalhadores.

Nota-se que em um moderno Estado Democrático de Direito, motivado pela dignidade humana, o clássico desempenho do Poder Judiciário tem sido insuficiente, tornando-se imprescindível ampliar a atividade judicante a fim de resguardar a saúde do trabalhador, cumprindo os direitos e garantias fundamentais como a inviolabilidade do direito à vida e à segurança, direitos humanos fundamentais. Imperativa que é a superioridade desses bens jurídicos, entende-se que nenhuma outra norma deverá prevalecer sobre o dever de rechaçar lesão ou ameaça à integridade do trabalhador.

Tal realidade provocou a iniciativa do Conselho Superior da Justiça do Trabalho (CSJT) em instituir o Programa Trabalho Seguro na Justiça do Trabalho. No intuito de fortalecer a Política de Nacional de Segurança e Saúde no Trabalho (PNSST), o programa visa formular e executar projetos e ações para promoção da saúde do trabalhador e prevenção de acidentes de trabalho, tendo a Resolução $n^{\circ} 96$ do CSJT estabelecido as diretrizes fundamentais como ações educativas, promoção de estudos e pesquisas, diálogo social e políticas públicas, além de eficiência jurisdicional e efetividade normativa.

Diante da gravidade e relevância do tema, vê-se a iniciativa do Judiciário para funções atípicas e não jurisdicionais que ultrapassam os limites dos tribunais, reforçando a defesa de necessário comportamento ativista também na intepretação e aplicação das normas para produção das decisões judiciais.

Revista do Direito [ISSN 1982-9957]. Santa Cruz do Sul, v. 2, n. 49, p. 154-170, maio/ago. 2016. https://online.unisc.br/seer/index.php/direito/index 


\section{DECISÃO JUDICIAL COMO FERRAMENTA ASSECURATÓRIA DA SAÚDE DOS TRABALHADORES}

Em demandas individuais, constatando dano causado ao empregado, ato ilícito cometido pelo empregador e nexo de causalidade entre o dano e as atividades laborais, o juiz condenará o empregador a ressarcir os prejuízos materiais e indenizar os danos morais e estéticos ocasionados. Todavia, os demais trabalhadores que laboram nas mesmas condições do reclamante acidentado podem ser potenciais vítimas, tornando-se necessário corrigir o provável desequilíbrio no ambiente laboral para prevenir novos infortúnios. Assim, a decisão proferida em um processo pode gerar efeitos positivos e negativos não apenas às partes que litigam, com também às classes de empregados e empregadores, não implicando dizer necessariamente que terceiros sejam submetidos aos efeitos da coisa julgada de uma ação individual, mas que efeitos comportamentais possam repercutir a partir dela.

Tomemos um exemplo de demanda acidentária que apresente pleitos de indenização pela aquisição de doença ocupacional letal e perda da capacidade para o trabalho. Constatados os pressupostos da responsabilidade civil, a empresa será condenada, mas o trabalhador ainda perderá a vida precocemente, pois os bens jurídicos violados não retornarão ao seu patrimônio, assim como não reviverá o pai do órfão e esposo da viúva. Por outro lado, o empregado será indiferentemente substituído na empresa.

Simples que possa ser o deslinde da ação individual, meios de provas como uma perícia técnica realizada por profissional especializado em segurança no trabalho ou uma inspeção judicial podem revelar um ambiente laboral com exposição dos empregados a graves riscos, sem que haja ações preventivas por parte do empregador como fornecimento de equipamentos de proteção eficientes para reduzir ou coibir os riscos. Resta analisar como decisões proferidas em ações individuais podem repercutir na vida dos demais trabalhadores.

Uma decisão judicial que condene empregador a pagar indenizações pelos danos ocasionados e pensão vitalícia em razão de perda permanente da capacidade para trabalhar a empregado que não utilizava EPI necessário poderá ser instrumento educativo ao réu e a terceiros. $O$ empregador condenado pode, espontaneamente, passar a fornecer o EPI regularmente aos demais empregados, mantendo rigorosa fiscalização quanto ao uso devido. Entretanto, ciente da resistência dos empregadores aos custos com segurança, faz-se imprescindível buscar meios ao alcance do Judiciário que protejam a vida de outros empregados submetidos àquele mesmo ambiente de trabalho desequilibrado. Os juízes poderiam adotar um comportamento proativo, motivando a decisão nos direitos humanos fundamentais resguardados pela Constituição Federal no intuito de impor obrigações de fazer para redução ou eliminação dos riscos, visando à segurança de todos os empregados.

Poderia, por exemplo, conferir maior publicidade à decisão, pois amplamente divulgada, pode repercutir em terceiros, estimulando a iniciativa de outros empregadores quanto à necessidade de utilização do EPI, alertando ao MTE e ao MPT quanto à necessidade de diligência na empresa condenada e em outras que atuem em idênticas condições, bem como proporcionando a classe 
trabalhadora conhecer os riscos, que poderá exigir do empregador o fornecimento, sob pena de rescisão indireta ou até interrupção do trabalho se julgar estar exposto a perigo iminente à vida ou saúde (art . 13 da Convenção №. 155 da OIT). Interpretando ampliativamente os textos normativos que se enquadrem aos pedidos autorais, o comando judicial poderia condenar o empregador a dar ampla divulgação da decisão condenatória em jornais de grande circulação, diretamente ou a título de ressarcimento ao erário. Diferentemente, se a decisão continuar desconhecida, repercutirá apenas no empregador condenado, quando o fizer suficientemente, não evidenciando a decisão caráter essencialmente punitivo, tampouco educativo.

Além disso, é preciso afetar "os bolsos" do empregador, sem comprometer a idoneidade financeira, estimular o investimento em segurança, sem causar desempregos, de forma a proferir decisões socialmente relevantes, sem ignorar os efeitos econômicos consequentes. Visando ao propósito, entende-se que interpretações restritivas mesmo diante de inquietante dano social revela inércia e preponderância de formalidades exacerbadas em detrimento dos direitos mais fundamentais do ser humano.

Nesse norte, caso sejam constatados graves riscos no ambiente de trabalho, a decisão judicial deve impor o cumprimento de medidas que protejam o maior número de trabalhadores. Afinal, um processo caracterizado por princípios que sopesam a hipossuficiência do empregado e o caráter alimentar da maioria dos pleitos, além de conferir simplicidade, celeridade e efetividade aos procedimentos, deve também visar ao bem comum da classe trabalhadora.

Outras formas de prezar pela saúde do trabalhador podem surgir a partir das peculiaridades dos casos concretos, a exemplo de crimes culposos de lesão corporal cometidos pelos empregadores. Devem ser comunicados ao Ministério Público competente a fim de viabilizar instauração de inquérito policial e inibir práticas ilícitas. Respondendo o empregador a processo criminal, haverá menos negligência com a segurança dos empregados.

Interessante também seriam atos extraprocessuais como o estabelecimento de convênios com órgãos públicos no propósito de impedir a participação de empregadores reincidentes em licitações. Atualmente, é possível obstaculizar a participação em certames licitatórios de empregadores inscritos no Banco Nacional de Devedores Trabalhistas (BNDT), haja vista a necessidade de Certidão Negativa de Débitos Trabalhistas (CNDT). Todavia, tal cadastro é constituído apenas por inadimplentes, atribuindo característica meramente financeira, permanecendo ilesos os agentes de ilícitos contra a vida. Torna-se interessante, portanto, um banco de dados oficial e público em que constem empregadores negligentes com a saúde e segurança, nele permanecendo por tempo razoável, determinado por lei ou decisão judicial.

Constatado o despreparo dos empregados no manuseio de máquinas e equipamentos, também poderia o magistrado, em atenção à função social da decisão, condenar a empresa culpada na obrigação de financiar e viabilizar cursos de capacitação e/ou próteses a mutilados. Caso o acidente tenha decorrido de desatenção em razão de jornada exaustiva, poderia condenar em adicional de horas extras maior que o mínimo de 50\% previsto na Constituição.

Existindo várias reclamatórias contra o mesmo empregador, audiências coletivas poderiam ser convocadas objetivando ampla composição, especialmente com intuito de corrigir riscos no 
ambiente de trabalho. Valorosa também seria a convocação de audiências especiais para ouvir classes de empregados e empregadores, habitualmente litigantes, no desígnio de compreender seus anseios e dificuldades e viabilizar uma solução global, prevenindo novos infortúnios. Tal hipótese demandaria tempo e bastante sensibilidade social, tornando-se difícil no contexto atual de metas dos tribunais.

Audiências públicas podem ser bastante relevantes em face da participação de amicus curiae, ou seja, personagens alheios às relações de trabalho em litígio, que podem emitir pareceres com conhecimentos especializados sobre a matéria em debate nos autos. São terceiros no processo que colaboram para elucidação de questões técnicas controvertidas, ampliando a discussão para que o órgão julgador tenha mais elementos para decidir legitimamente, tendo em vista que o conhecimento jurídico que detém se torna insuficiente e deve ser somado ao conhecimento técnico especializado daqueles. No processo do trabalho, profissionais especializados em segurança no trabalho ou em doenças ocupacionais podem contribuir com esclarecimentos relevantes para adoção de medidas preventivas em ramos ou empresas cuja incidência acidentária seja elevada, bem como acerca de agentes físicos ou químicos a que ficam expostos os trabalhadores em determinado ambiente de trabalho.

Audiências públicas são comuns no Supremo Tribunal Federal, que trata de matérias de repercussão geral, a exemplo da audiência pública convocada em 2012 na Ação Direta de Inconstitucionalidade (ADI) 3937 contra lei paulista que proíbe o uso de produtos que contenham amianto ou asbesto. Para debater a utilização do amianto na indústria brasileira, participaram como amicus curiae diversos especialistas entre médicos, engenheiros, químicos, professores etc, que forneceram informações especializadas para cooperar na conciliação de valores igualmente constitucionais, mas contrapostos na situação específica: iniciativa privada, proteção ao meio ambiente e saúde dos trabalhadores e cidadãos em geral.

Apesar de reconhecido pela Organização Mundial da Saúde como substância cancerígena, o Brasil permanece entre os quatro maiores produtores do mineral, não se concebendo a morosidade numa decisão que envolve a saúde pública, com indícios danosos internacionalmente reconhecidos, vez que a celeridade nos julgamentos que envolvem a saúde é essencial na sua proteção. Ainda que hajam dúvidas quanto às lesões, cabe aplicar o princípio da precaução, pois em face da incerteza científica do dano, a atividade econômica não pode ser realizada em face do princípio in dubio pro operário, pois o excesso de cautela em prol da sadia qualidade de vida deve prevalecer em detrimento da iniciativa privada. Entretanto, para amenizar os danos da paralização de uma atividade econômica, o Estado pode cooperar na substituição do elemento danoso através de parcerias em estudos científicos.

Outro meio de buscar implementar a saúde do trabalhador seria impor à empresa contratar técnicos de segurança no trabalho, quando constatado o descumprimento das normas de segurança que estabelecem a existência de tal profissional. Neste caso, além da solução reduzir a insegurança dos trabalhadores na empresa, comina o cumprimento de normas inobservadas, contribuindo para ampliação do mercado de trabalho e para pleno emprego. 
Percebe-se que os exemplos podem ser utilizados em propostas conciliatórias de iniciativa do juiz, assim como podem surgir em decisões criativas e proativas, que consigam aplicar os direitos constitucionais materiais e processuais, ou seja, efetivar os direitos fundamentais, de forma coletiva e difusa, sem implicar, por óbvio, a infração do devido processo legal. Cabe ao Estado, portanto, promover um modelo socioeconômico justo, observando a função social da decisão judicial.

Ocorre que resguardar a saúde de um universo de trabalhadores em ação judicial coletiva é impor a devida relevância amparado pela legislação processual, mas fazê-lo em demandas individuais ou ações extraprocessuais requer do magistrado empenho além do demandado. É necessária a coleta de elementos probatórios bastante consistentes, frequentemente produzidos de ofício; maior dedicação de tempo e qualificação para apresentação de boa fundamentação; consciência da realidade social; interesse em promover solução coletiva, coragem para enfrentar o padrão tradicional e razoabilidade para não agir de forma desproporcional e cometer arbitrariedades. A decisão importa em um trabalho intelectual precedido de análise cuidadosa dos elementos intraprocessuais e extraprocessuais, devendo ser elaborada com ponderação e fundamentos sólidos, no intuito de alcançar uma solução justa e eficaz através de adequada prestação jurisdicional.

Vale registrar que, conquanto as alternativas mencionadas possam ser entendidas pelo empregador como pouco interessantes para seu empreendimento, notadamente no que se refere ao aspecto financeiro da questão, não constituem inobservância à imparcialidade de que deve se revestir a ação estatal, pois o objetivo delas é o cumprimento da ordem jurídica, consolidando direitos fundamentais dispostos no topo normativo. A interferência do Estado Judicante nas atividades econômicas em favor da existência digna se alinha aos princípios constitucionais da ordem econômica como a função social da propriedade, a busca do pleno emprego, a redução das desigualdades sociais e a defesa do meio ambiente, nele compreendido o do trabalho. Neste sentido, a atuação jurisdicional harmoniza a livre iniciativa com a valorização do trabalho humano, a qual inexistirá, caso suprimida a saúde do trabalhador.

Além disso, não se pode considerar as medidas como imposição de ônus extrafiscais a prejudicar a higidez financeira das empresas, pois se os empregadores cumprissem as normas espontaneamente, independentemente de atuação fiscalizatória ou jurisdicional, certamente seriam poupados de muitas despesas como indenizações aos empregados vitimados ou ao órgão gestor de benefícios previdenciários, multas administrativas, honorários advocatícios e periciais, custos extraordinários ocasionados pela própria negligência.

Conclui-se que, respeitado o direito do empregador ao contraditório e à ampla defesa, bem como observado o princípio da motivação dos atos decisórios, torna-se imprescindível a iniciativa do magistrado para dar máxima efetividade à Constituição e garantir direitos fundamentais. Se o direito processual é instrumentalizador do direito material, não lhe deve sobrepor ou obstaculizar, porquanto sua efetivação deve representar a própria garantia do direito material, razão porque a criatividade judicial na solução das demandas viabiliza a aplicação equânime de ambos, respeitando o devido processo legal sem o tornar empecilho a garantia dos direitos fundamentais amplamente considerados em demandas individuais, como, por exemplo, sobrepor irrestritamente o princípio da inércia da jurisdição em casos de danos sociais. Neste sentido, a atuação proativa do Poder 
Judiciário surgiria para ponderar os dogmas processuais e materializar a saúde do trabalhador, conferindo a devida relevância à função social da decisão judicial, tendo em vista que a substituição do Estado para solução dos conflitos particulares deve observar não apenas os interesses individuais permeados, mas também o bem-estar social, objetivo anteposto a toda norma jurídica e toda atuação estatal.

Portanto, é possível verificar que o apego técnico processual que obstaculiza a solução efetiva das demandas judiciais tem sido substituído pela preocupação com o desenvolvimento social, especialmente nos órgãos de primeira instância, cujas decisões emanam de juízes mais próximos à sociedade e a quem cabe a produção das provas. Conferir um julgamento legalmente coerente e socialmente justo exige maior dedicação de tempo, esforço e engenhosidade na análise das provas e das normas.

Diversos princípios de direito processual demonstram a preocupação humana e social do processo, como o princípio do ativismo judicial, pelo qual cabe manter postura ativista no processo para atingir a verdade real. Igualmente conexo está o princípio da finalidade social (THEODORO Jr, 1998, p. 62), específico do processo do trabalho, tendo em vista que permite ao juiz atuar em proteção do hipossuficiente em face de qualquer iniquidade legal. A observância de tais princípios atende ao art. 5 da LINDB, o qual disciplina que "Na aplicação da lei, o juiz atenderá aos fins sociais a que ela se dirige e às exigências do bem comum", texto semelhante ao previsto no $\S 1^{\circ}$ do art. 852-I da CLT, que, tratando da elaboração da sentença, afirma que "O juízo adotará em cada caso a decisão que reputar mais justa e equânime, atendendo aos fins sociais da lei e às exigências do bem comum".

Revela-se difícil a observância de tais princípios e exercício da melhor atividade jurisdicional em razão da alta incidência de demandas e crescente pressão por produção, com exigência de metas e prazos independentemente de volume, complexidade e relevância da matéria. Apesar disso, muitas decisões evidenciam valores sociais, especialmente nos juízos de primeiro grau, embora sejam comumente reformadas em instância superior, o que demonstra a necessidade de humanização do processo em todas as instâncias, além de fundamentação sólida e irrefragável das sentenças para convencimento das partes e órgãos superiores.

Buscando os fins sociais e o bem comum, é possível encontrar meios eficientes como obrigações de fazer assumidas em conciliação entre as partes, momento em que podem renunciar direitos e ampliar os deveres, estabelecendo medidas de correção pacificamente condescendidas. No TRT13, nos autos da Ação Civil Pública oㅡ 0098900-67.2014.5.13.0025 promovida pelo MPT em face do SENAI - Serviço Nacional de Aprendizagem Industrial e da Norfil S.A. Indústria Têxtil, o juiz conduziu e homologou acordo em que a primeira ré promoveria a primeira turma do Curso de Operador de Processos da Indústria Têxtil da Paraíba, enquanto a segunda ré contrataria o número de aprendizes no percentual previsto no art. 429 da CLT, sendo estes os objetos da lide. Mas a concretização do acordo excedeu os limites dos pedidos na medida em que a NORFIL disponibilizou seu parque fabril para a realização das aulas práticas, e que o SENAl se comprometeu a consultar outras empresas do mesmo setor acerca de idêntica demanda de aprendizes, suprindo também necessidade de outras empresas e dando maior eficiência à norma, haja vista possibilitar seu 
cumprimento pelas demais empresas do setor. O objeto da ação ministerial, de grande relevância para fomento da inclusão no mercado de trabalho e treinamento eficaz para exercício das atividades e redução de acidentes, obteve maior papel social com a ampliação das obrigações dadas em comum acordo. Tal postura poderia ser praticada em mais oportunidades, não havendo impedimento legal a uma composição que ultrapasse os limites dos pedidos, conferindo efetividade social e normativa, inclusive nos autos de ações individuais em que, por exemplo, tenha se verificado acidente grave por ausência de formação e inabilidade técnica.

Outra alternativa corretiva seria condenar a empresa infratora ao pagamento de multas ou indenizações suplementares reversíveis à sociedade, a exemplo das indenizações pela prática de dumping social, veementemente condenada pelo Direito Internacional diante do dano à ordem econômica e jurídica, na qual as empresas violam direitos dos trabalhadores, submetendo-os a condições degradantes e de riscos, no intuito de auferir vantagens com a redução dos custos da produção para barateamento dos produtos objetivando a eliminação da concorrência. Nesses casos, a saúde dos trabalhadores é exposta a perigos, principalmente em razão das jornadas de trabalho extenuantes e das péssimas condições do meio ambiente do trabalho. Condenar empresas transgressoras a pagar indenizações suplementares revertidas à sociedade é um meio de impor punição pela infração aos direitos fundamentais da classe trabalhadora e ainda evitar reincidência, ampliando a decisão de instrumento de reparação de uma vítima para solução de um problema social.

Foi o que fez o juiz na Ação Trabalhista $n^{\circ}$ 0024800-18.2012.5.13.0024, condenando empresa insistentemente reincidente a pagar indenização suplementar por danos sociais. Porém a sentença foi reformada na segunda instância, que considerou a sentença infratora do princípio da proibição de julgamento extra petita. Ao excluir da condenação a indenização suplementar por danos sociais, reduzir o valor da indenização por danos morais e excluir os lucros cessantes, a decisão não cumpriu seu papel social, haja vista que ignorou os consistentes fundamentos da decisão e se apegou à dita "infração" processual, em favor da infração de direitos fundamentais constitucionais, abstendo-se de inibir desmedidas ilicitudes.

Hipótese de interpretação desfavorável à saúde é a jurisprudência tradicionalmente consolidada pela impossibilidade de acumulação dos adicionais de insalubridade e periculosidade. $\mathrm{O}$ art. 193, §2 da CLT aponta que o empregado deve optar entre um deles, quando submetido a ambos, enquanto a Constituição, em seu art. $7^{\circ}$, XXIII, elenca como direitos dos trabalhadores a percepção de adicional em razão de atividades penosas, insalubres ou perigosas, sem indicar ressalvas de não cumulatividade. Ora, prezando a Constituição de 1988 tão nitidamente pelos direitos sociais, entre eles a saúde, a regra de 1943 prevista na CLT certamente não foi recepcionada. Neste sentido, a $7^{\text {a }}$ Turma do TST vem apresentando uma releitura da legislação defendendo que as normas constitucionais e supralegais, hierarquicamente superiores à CLT, autorizam a cumulação dos adicionais, fazendo menção também às Convenções 148 e 155 da Organização Internacional do Trabalho (OIT) introduzidas no sistema jurídico brasileiro, cujos parâmetros seguem algumas decisões a exemplo dos recursos de revistas no 1072-72.2011.5.02.0384 (2014) e 24390520115150018 (2015), e da sentença proferida no TRT13 no $0130736-24.2015 .5 .13 .0025$ 
(2016). Ocorre que a jurisprudência contrária é predominante, tendo em vista os vários processos pesquisados no TRT13, a exemplo do 0037100-38.2014.5.13.0025, no qual a inacumulatividade dita na sentença foi confirmada por acórdão em recurso ordinário.

Acrescente-se decisão recente do TST (em ARR-1081.60.2012.5.03.0064, de 28 abr. 2016), através da SBDI-I, pela impossibilidade de tal acumulação e prevalência do art, 193, §2 da CLT ante as Convenções supra referidas, sob o argumento de que embora tenham sido incorporadas ao ordenamento jurídico brasileiro, "não se sobrepõem à norma interna que consagra entendimento diametralmente oposto, aplicando-se tão somente às situações ainda não reguladas por lei". Tal decisão parece ignorar o entendimento doutrinário de que, uma vez ratificadas, as Convenções assumem caráter minimamente de lei no ordenamento jurídico brasileiro, cabendo observar as regras hermenêuticas como temporalidade das leis, haja vista que as Convenções 148 e 155 foram ingressas em 1982 e 1992, respectivamente, após a Consolidação Trabalhista, de 1943. Além disso, não é incomum no texto consolidado a existência de normas obsoletas, inaplicáveis e desprovidas de atualização, a exemplo da figura dos juízes classistas e das Juntas de Conciliação e Julgamento. Seria possível apresentar vários fundamentos para a lamentável decisão, entretanto, basta aqui apresentarmos os obstáculos jurisprudenciais no enfrentamento da matéria.

É possível observar que a nova corrente jurisprudencial tem como mais forte fundamento a efetividade das normas constitucionais e supralegais, protegendo a saúde do trabalhador, haja vista que os adicionais de insalubridade e periculosidade tem fatos geradores diferentes e protegem bens jurídicos também diferentes, saúde e vida, respectivamente. Portanto, nestes casos, os empregados são submetidos a riscos diferentes e cumulativos, não havendo razão para beneficiar a atividade econômica em detrimento do trabalhador.

Embora haja inúmeros outros casos, com apenas estes exemplos, percebe-se a força do Judiciário em garantir o direito à saúde do trabalhador, embora muitas vezes sejam necessários contornos processuais comumente resistidos pelos operadores mais conservadores e legalistas. Destinar mais tempo e dedicação é imprescindível nas ações acidentárias, pois podem ser averiguadas propostas de melhorias no meio ambiente do trabalho que beneficiem vários trabalhadores, além do litigante. É necessário promover o acesso à verdadeira justiça, rechaçando os pretextos de incompetência ou limites de atuação em prol do bem jurídico mais importante: a vida.

\section{CONSIDERAÇÕES FINAIS}

Ao longo do presente texto, demonstraram-se várias dificuldades enfrentadas pelo Poder Judiciário em promover a saúde no meio ambiente laboral, notadamente em razão da conformação clássica da divisão dos poderes e consequente limitação às formalidades legislativas, as quais podem representar óbices à efetivação do direito constitucional à saúde.

O problema elaborado e informado na abordagem introdutória traduz-se em buscar saber que possibilidades o Poder Judiciário teria, à luz da Constituição Federal, de concorrer para a promoção da sadia qualidade de vida do trabalhador no meio ambiente laboral, tendo-se em conta que uma decisão judicial obedece a limitações que se vinculam à clássica repartição dos poderes. Na mesma 
sede, considerou-se, enquanto hipótese, que a atuação do Poder Judiciário pode ser feita através da proatividade judicial, adotando-se teorias realistas para interpretação das normas e seguindo as correntes que conferem máxima efetividade ao direito fundamental à saúde.

Neste sentido, considera-se a hipótese apontada como factível, tendo em vista concluir que a divisão de funções dos poderes não afasta o objetivo comum de consolidar o Estado Democrático de Direito com a efetivação da Constituição Federal, ainda que seja necessária a criatividade interpretativa e relativização de teorias consolidadas, posto que nada é definitivamente imutável.

Por conseguinte, a decisão judicial carece de comportamento proativo na interpretação e aplicação das normas, para assegurar a saúde do trabalhador e atender o fim social da prestação jurisdicional. Nessa perspectiva, parece incoerente engessar o Judiciário em linhas formais, sendo mais plausível o investimento em decisões criativas não obstaculizantes, devendo o juiz, sem hesitar, tomar partido pelo bem da vida, acautelando-a sempre que a ameaça for temerosa e houver alternativas jurídicas sensatas para sua proteção.

Com efeito, valer-se de métodos pragmáticos de interpretação das normas para conferir solução justa e eficiente, não significa ignorar comandos legais ou conceder poderes ilimitados a juízes, legitimando arbitrariedades. A decisão judicial deve partir da hermenêutica e da retórica, cabendo ao julgador proceder à análise das provas, identificar o direito violado ou em risco e, abalizado no ordenamento jurídico vigente, somado ao discurso de convencimento, conferir a justa decisão para melhor resguardar direitos fundamentais, sem ignorar os efeitos socioeconômicos que a decisão possa surtir para a sociedade. Logo, o julgador deve enfrentar obstáculos jurisprudenciais para oferecer segurança jurídica aos jurisdicionados, sem atalhar a concretização de direitos sociais, valendo-se da aplicação do princípio da máxima efetividade das normas constitucionais e da regra de interpretação conforme à Constituição.

Por fim, vale o registro de que a saúde do trabalhador deve ser assumida como compromisso social, de forma que o papel do Judiciário e suas decisões tenham poder instrumentalizador e educacional no mercado de trabalho, cabendo ao magistrado proporcionar a valorização do trabalho e promover a justiça a partir da interpretação e aplicação das normas na elaboração das decisões judiciais.

\section{REFERÊNCIAS}

ADEODATO, João Maurício. Adeus à separação de poderes? Chegando à tese do realismo jurídico. O direito como atividade judicial. Org. Enoque Feitosa... [et al.]. Recife: Ed. Dos Organizadores, 2009, p. 23-44.

ANTUNES, Ricardo. O caracol e sua concha. São Paulo: Boitempo, 2005.

BARBOZA, Estefânia Maria de Queiroz; KOZICKI, Katya. Judicialização da política e controle judicial de políticas públicas. Rev. direito GV, São Paulo, v. 8, n. 1, p. 059-085, June 2012. Disponível em: <http://www.scielo.br/scielo.php?script=sci_arttext\&pid=S180824322012000100003\&lng=en\&nrm=iso>. Acesso em: 11 July 2015.

BRASIL. Tribunal Regional do Trabalho (13. Região). TRT condena empresa por dumping social. Disponível em: <https://www.trt13.jus.br/informe-se/noticias/2012/08/trt-condena-empresa-pordumping-social>. Acesso em 11 jul. 2014. 
Ministério da Previdência Social. Segurança e saúde ocupacional. Disponível em: $<$ http://www.previdencia.gov.br/a-previdencia/saude-e-seguranca-ocupacional/>. Acesso em 27 jul. 2014

CARDOZO, Benjamin N. A natureza do processo judicial: palestras proferidas na Universidade de Yale. Trad. Silvana Vieira. Rev. Álvaro De Vita. São Paulo: Martins Fontes, 2004.

CASTRO, Hermano Albuquerque de. Brasil: rumo à eliminação do asbesto/amianto. Cad. Saúde Pública, Rio de Janeiro, v. 28, n. 5, p. 816-817,May 2012. Disponível em: $<$ http://www.scielo.br/scielo.php?script=sci_arttext\&pid=S0102-311X2012000500001\&lng

$=$ en\&nrm=iso>. Acesso em: 24 July 2015.

FREITAS, Lorena. O elemento subconsciente na decisão judicial conforme o realismo jurídico de Benjamin Nathan Cardozo. 0 direito como atividade judicial. Org. Enoque Feitosa... [et al.]. Recife: Ed. Dos Organizadores, 2009, p. 137-147.

GOMES, Nestor Castilho. A teoria da norma de Friedrich Müller: reflexos na metódica jurídica. Dissertação apresentada ao Programa de Mestrado do Curso de Pós-graduação em Direito da Universidade Federal de Santa Catarina. Disponível em: <http://www.dominiopublico.gov.br/download/teste/arqs/cp094974.pdf> Acesso em 07 jul. 2015

KELSEN, Hans. Teoria pura do direito. Trad. João Baptista Machado. 6. ed. São Paulo: Martins Fontes, 1998. Disponível em: <http://www.estig.ipbeja.pt/ ac_direito/HansKelsen Teoria.pdf>. Acesso em 05 jul. 2015.

MELLO, Cláudio Ari. Democracia constitucional e direitos fundamentais. Porto Alegre: Livraria do Advogado, 2004.

MÜLLER, Friedrich. Métodos de trabalho no direito constitucional. $3^{\mathrm{a}}$ ed. rev. e ampliada. Rio de Janeiro: Renovar, 2005.

NASCIMENTO, Amauri Mascaro. A sentença normativa e o direito do trabalho. Revista da Faculdade de Direito de São Paulo, v. 75, p. 67-78, 1980.

STRECK, Lenio Luiz. Aplicar a "letra da lei" é uma atitude positivista? Novos estudos jurídicos Revista eletrônica, Vol. 15 - n. 1- p. 158/173, jan-abr. Itajaí: Ed. Da Universidade do Vale do Itajaí, 2010. Disponível em: <http://siaiweb06.univali.br/seer/index.php/nej/article/view/2308>. Acesso em: 26 jul. 2015.

THEODORO Jr., Humberto. Os princípios do Direito Processual Civil e o Processo do Trabalho. In: BARROS, Alice Monteiro de (Coord.). Compêndio de Direito Processual do Trabalho: obra em homenagem a Celso Agrícola Barbi. 1. ed. São Paulo: LTr, 1998.

VIANNA, Luiz Werneck; BURGOS, Marcelo Baumann; SALLES, Paula Martins. Dezessete anos de judicialização da política. Tempo soc., São Paulo, v. 19, n. 2, p. 39-85, Nov. 2007. Disponível em $<$ http://www.scielo.br/scielo.php?script=sci_arttext\&pid=S0103-207020070

$00200002 \& \operatorname{lng}=e n \& n r m=i s 0>$. Acesso em: 11 jul.2015.

\section{COMO CITAR ESSE DOCUMENTO}

PIMENTEL, Catarine Helena Limeira; CECATO, Maria Áurea Baroni. O papel político do Poder Judiciário na efetivação do direito à saúde do trabalhador: enfoque nas demandas acidentárias. Revista do Direito, Santa Cruz do Sul, v. 2, n. 49, maio 2016. ISSN 1982-9957. Disponível em: $<$ https://online.unisc.br/seer/index.php/direito/article/view/8110>. Acesso em: doi:http://dx.doi.org/10.17058/rdunisc.v2i49.8110. 